\title{
IMMUNOHISTOCHEMICAL APPROACH REVEALS LOCALIZATION OF CYSTATHIONINE- $\gamma$-LYASE AND CYSTATHIONINE-B-SYNTHETASE IN ETHANOL-INDUCED GASTRIC MUCOSA DAMAGE IN MICE
}

\author{
Jand-Venes Rolim MEDEIROS ${ }^{1}$, Pedro Marcos Gomes SOARES², \\ Gerly Anne de Castro BRITO² and Marcellus Henrique Loiola Ponte de SOUZA ${ }^{2}$
}

\begin{abstract}
Context - Hydrogen sulphide $\left(\mathrm{H}_{2} \mathrm{~S}\right)$ has been proved to be a neuromodulator and contributes to the maintenance of gastric mucosal integrity in damage caused by anti-inflammatory nonsteroidal drugs. Previously, we demonstrated that $\mathrm{H}_{2} \mathrm{~S}$ synthesis is essential to gastric protection against ethanol. Objective - To better understanding the role of $\mathrm{H}_{2} \mathrm{~S}$ and the detailed localization of its production in both normal and injured stomach due to ethanol injection, we studied the expression of cystathionine- $\gamma$-lyase (CSE) and cystathionine- $\beta$-synthetase (CBS) isoforms in gastric mucosa of mice treated with saline or 50\% ethanol. Methods - Mice were treated by gavage with saline or $50 \%$ ethanol $(0.5 \mathrm{~mL} / 25 \mathrm{~g})$. After 1 hour, mice were sacrificed, and gastric tissue was evaluated by histological and immunohistochemical analysis specific for CSE and CBS. Results - We have demonstrated a non-specific expression of CBS in the normal gastric mucosa and expression of CSE occurring mainly in the parietal cells of the animals treated with ethanol. Conclusion - Thus, we demonstrated that the expression of CBS appears to be constitutive and diffuse across the gastric epithelium, while the expression of CSE appears to be induced in parietal cells by damage agents such as ethanol.
\end{abstract}

HEADINGS - Gastric mucosa. Cystathionine- $\beta$-Synthase. Cystathionine- $\gamma$-Lyase. Ethanol. Immunohistochemistry. Mice.

\section{INTRODUCTION}

Ethanol ingestion causes acute gastric mucosal lesions in humans ${ }^{(5)}$. Ethanol-induced gastric damage is characterized by epithelial cellular loss, mucosal edema and subepithelial hemorrhage ${ }^{(6,9)}$. The molecular mechanism of ethanol-induced gastric injury has not yet been completely elucidated.

Hydrogen sulfide $\left(\mathrm{H}_{2} \mathrm{~S}\right)$ is a gaseous transmitter involved in a multitude of physiologic functions, which includes immune and inflammatory processes ${ }^{(2)}$, perception, and pain mediation, as well as control of gastric mucosal integrity, vascular tone, and the control of gastrointestinal motility ${ }^{(4)}$. $\mathrm{H}_{2} \mathrm{~S}$ is synthesized endogenously from L-cysteine, primarily via two enzymes: cystathionine- $\gamma$-lyase (CSE) and cystathionine- $\beta$-synthetase $(\mathrm{CBS})^{(9)}$. CBS and CSE are expressed in a different extent in neurons in the brain and in the enteric nervous system ${ }^{(9)}$. Recent studies suggest that $\mathrm{H}_{2} \mathrm{~S}$ may similarly contribute to mucosal defense $^{(3,10)}$. The gastric mucosa expresses both CSE and CBS and has the ability to generate $\mathrm{H}_{2} \mathrm{~S}$, but CSE seems to be the main enzyme involved in the $\mathrm{H}_{2} \mathrm{~S}$ generation by the gastric mucosa ${ }^{(3,4)}$.

The mechanism through which $\mathrm{H}_{2} \mathrm{~S}$ protects the stomach from damage due to ethanol has not been completely elucidated. Therefore, the aim of this study was to determine the effect of ethanol on the immunoexpression of CSE/CBS in the gastric mucosa of mice.

\section{METHODS}

\section{Animals procedures}

Male Swiss mice ( $25 \mathrm{~g}-30 \mathrm{~g})$ were fasted $18 \mathrm{~h}$ to $24 \mathrm{~h}$ before the experiments. All animal treatments and surgical procedures of the present study were performed in accordance with the ethical principles of the Federal Law 11.794 (October 2008) and Decree 66689 (July 2009) dictated by the Brazilian Society of Animal Science Laboratory (SBCAL) and revised and approved by the local ethics committee (UFPI protocol 63/07).

Declared conflict of interest of all authors: none

Biotechnology and Biodiversity Center Research (BIOTEC), Federal University of Piauí, Campus de Parnaíba, Parnaíba, PI, Brazil; ${ }^{2}$ Brazilian Semi-Arid Institute of Biomedicine (INCT-IBISAB), Departament of Physiology and Pharmacology, Federal University of Ceará, Fortaleza, CE, Brazil.

Correspondence: Prof. Jand-Venes Rolim Medeiros - Biotechnology and Biodiversity Center Research (BIOTEC), Universidade Federal do Piauí, Campus de Parnaíba Av. São Sebastião, 2819 - Reis Veloso - 64202-020 - Parnaíba, PI, Brazil. E-mail: jandvenes@ufpi.edu.br 


\section{Tissue collection and immunohistochemical assay}

The present study used 10 mice and was divided into two groups: normal group (treated only saline) or $50 \%$ ethanol $(0.5 \mathrm{~mL} / 25 \mathrm{~g})$. One hour later, the animals were sacrificed after being weighed and anesthetized with $40 \mathrm{mg} / \mathrm{kg}$ of intraperitoneal thiopental (Abbott Laboratories, Chicago, IL, USA). The stomachs were rapidly removed and a sample of the corpus region was fixed in $10 \%$ neutral buffered formalin solution, sectioned and embedded in paraffin to histological analysis.

Specific immunohistochemistry for cystathionine $\gamma$-lyase (CSE) and cystathionine $\beta$-synthase (CBS) was performed according to Costa et al. ${ }^{(1)}$. The gastric mucosal cells were identified by their specific morphology, localization and staining behavior and their total number was counted at $\times 250$ magnification. Each microscopic slide contained three portions of the $5 \mathrm{~cm}$ gastric mucosa segment. A pathologist blinded to the experimental conditions used a light microscope to count all the immunopositive cells. Three full countings were performed, and the last counting results were used in the analysis. The gastric chief cell, parietal cells and mucosal cells were counted.

\section{Statistical analysis}

All values are expressed as means \pm SEM. ANOVA and student test $t$ were used to determine statistical significance of differences between groups. Differences were considered to be significant when $P<0.05$.

\section{RESULTS}

Figure 1 show that ethanol administration increased the CSE immunoexpression exclusively in the parietal cell and all gastric mucosal cells express CBS. In control group (saline alone) the immunostaining to CBS was especially seen in chief cells, although it was also observed some immunostaining in the mucosal cells (Figure 1 - panel B and Table 1). However, the animal treatment with ethanol 50\% was accompanied by a wider parietal cells staining (Figure 1 - panel C and Table 1). Unlike CBS, there was no significant immunostaining of CSE in the control group (Figure 1 - panel D and Table 1). However, in animals treated with ethanol $50 \%$, CSE was notably expressed in parietal cells (Figure 1 - panel E).
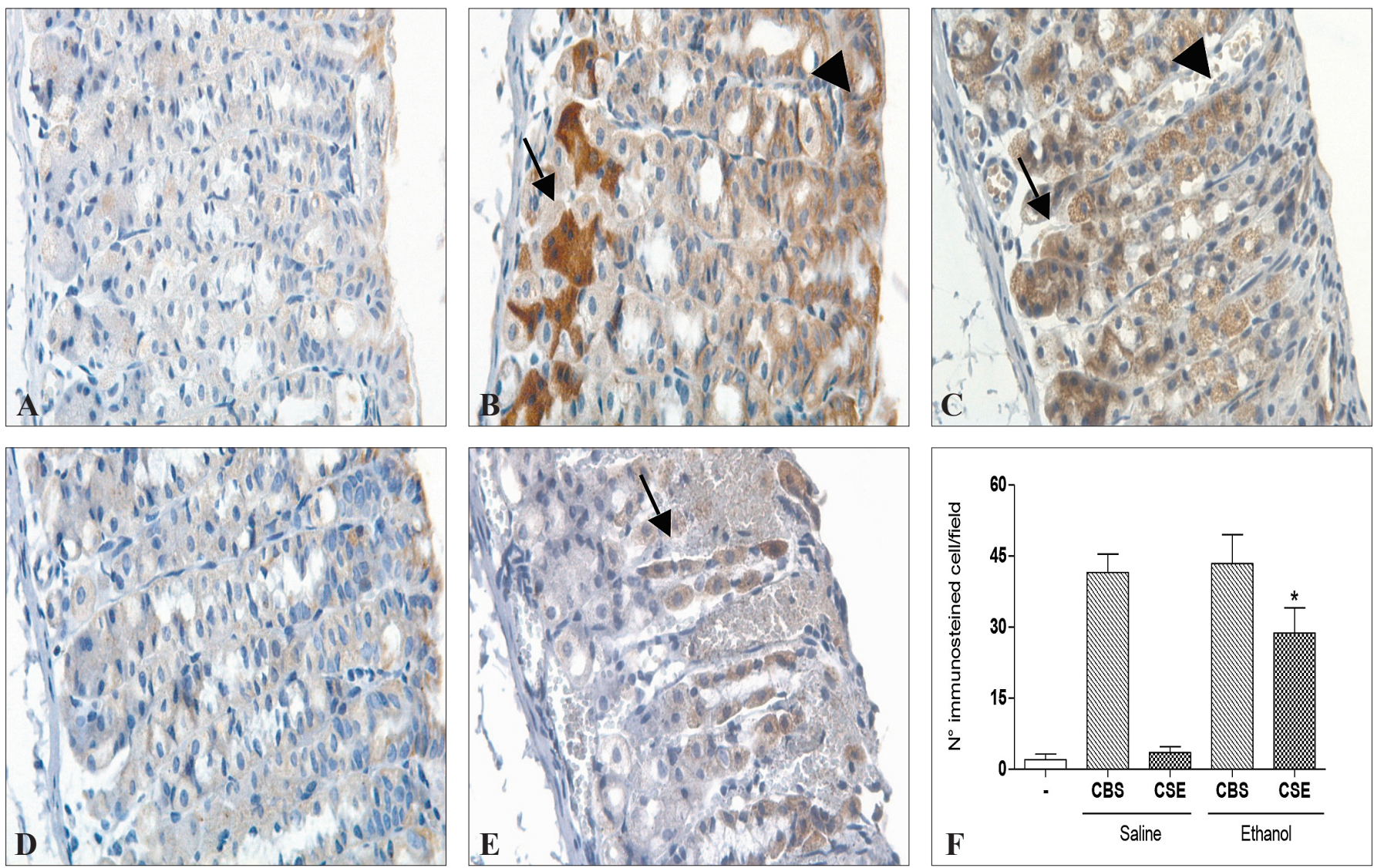

FIGURE 1. Immunohistochemical features of cystathionine $\gamma$-lyase (CBS) and cystathionine $\beta$-synthetase (CSE) in the gastric mucosa of normal mice and ethanol-induced gastric damage. (A) Negative control (immune-negative cells); (B-C) Immunostaining for CBS in the stomach of an animal treated only with saline (panel B) or treated with ethanol 50\% (panel C) with arrows marking indicating the chief cells and arrowheads indicate labeling in mucosal cells (panel B) or parietal cells (panel C). (D-E) There was no significant immunostaining of CSE in the control group (panel D). However, in animals treated with ethanol 50\%, was observed to mark CSE in parietal cells (panel E) and some mucosal cells. (F) Counting of CBS and CSE positive immunostained cells (five animals from each group). The results are presented as means \pm S.E.M. $*<0.05$ vs saline + CSE group 
TABLE 1. Ethanol effect on the immunohistochemical expression of CBS and CSE in gastric mucosa cells of mice

\begin{tabular}{|c|c|c|c|c|}
\hline Experimental group & Enzyme & $\begin{array}{l}\text { Number of chief } \\
\text { cells }\end{array}$ & $\begin{array}{l}\text { Number of parietal } \\
\text { cells }\end{array}$ & $\begin{array}{l}\text { Number of mucosa } \\
\text { cells }\end{array}$ \\
\hline Saline & CBS & $19.3 \pm 2.1$ & $8.9 \pm 1.7$ & $24.5 \pm 4.3$ \\
\hline Saline & CSE & $2.2 \pm 1.0$ & $3.1 \pm 1.2$ & $3.2 \pm 2.3$ \\
\hline Ethanol & CBS & $23.8 \pm 5.2$ & $19.2 \pm 4.2^{\mathrm{a}}$ & $9.6 \pm 2.3^{\mathrm{a}}$ \\
\hline Ethanol & CSE & $8.8 \pm 3.3$ & $21.9 \pm 2.2^{\mathrm{b}}$ & $12.5 \pm 1.0^{\mathrm{b}}$ \\
\hline
\end{tabular}

Results are mean \pm SEM of $5-6$ mice. ${ }^{\text {a }} P<0.05$, when compared with CBS in saline group; ${ }^{\mathrm{b}} P<0.05$, when compared with CSE in saline group

\section{DISCUSSION}

It was demonstrated that $\mathrm{H}_{2} \mathrm{~S}$ contributes to the maintenance of gastric mucosal integrity in damage caused by nonsteroidal anti-inflammatory drugs ${ }^{(10)}$ and ethanol ${ }^{(3)}$. In the present study, we evaluated the ethanol effect on the immunohistochemical expression of CBS and CSE in gastric mucosa of mice. Cystathionine- $\gamma$-lyase (CSE) and cystathionine- $\beta$-synthase (CBS) can use L-cysteine as an alternative substrate to form hydrogen sulfide $\left(\mathrm{H}_{2} \mathrm{~S}\right)$. The gastric mucosa expresses both CSE and CBS and has the ability to generate $\mathrm{H}_{2} \mathrm{~S}^{(10)}$, and CSE seems to be the main enzyme involved in the $\mathrm{H}_{2} \mathrm{~S}$ generation by the gastric mucosa ${ }^{(9,10)}$.

Detailed localization of CSE and CBS in stomach has not yet been evaluated and general agressors has ability to modulate CSE expression, but they do not affect CBS expression. Our results clearly showed that administration of ethanol resulted in an increased immunostaining of CSE but not of CBS in the gastric wall. We results demonstrated that the control group (saline) showed only immunostailing of CBS, that was expression mainly in chief and mucosal cells. However, after ethanol administration, there was also expression in parietal cells. Likewise, the ethanol promotes expressions of CSE in parietal cells. Our findings show that ethanol promotes an increase in coexpression of CSE especially in the parietal cells, suggesting that these cells may be mainly responsible for the synthesis of $\mathrm{H}_{2} \mathrm{~S}$ involved stomach gastroprotection. In fact, we previously demonstrated that $\mathrm{H}_{2} \mathrm{~S}$ donor and $\mathrm{H}_{2} \mathrm{~S}$ precursor (L-cysteine) decreased ethanol-induced gastropathy ${ }^{(10)}$. Thus, this increase expression of CSE may be a mechanism of defense against the ethanol-induced gastric damage.

Little is known about the cellular consequences of an elevated CSE expression or about the associated increase in endogenously produced $\mathrm{H}_{2} \mathrm{~S}$. CSE-derived $\mathrm{H}_{2} \mathrm{~S}$ inhibits cell proliferation $^{(8,14)}$ and induces cell death predominantly by an apoptotic mechanism in polymorphonuclear cells $\mathrm{s}^{(11,13)}$. Deficiency of CSE activity in humans is presumed to cause cystathioninemia (cystathioninuria), an autosomal recessive inborn error probably with no consistent clinical consequence $^{(12,14)}$.
The CSE transcript, protein and enzymatic activity were detected in liver, kidney, and, at much lower levels, in small intestine and stomach of both rats and mice. Immunohistochemical analyses revealed predominant CSE expression in hepatocytes and kidney cortical tubuli ${ }^{(7)}$. These results suggest important physiological roles for CSE in mice. We demonstrated that, after ethanol administration, almost all gastric mucosal cells express CBS while the expression of CSE occurs almost exclusively in the parietal cell. These results showed that the gastric epithelium therefore could be one source of $\mathrm{H}_{2} \mathrm{~S}$ in the gastric wall. Furthermore, the coexpression of $\mathrm{CSE}^{2}$ and CBS in gastric mucosal might be an indication that they are equally involved in the production of $\mathrm{H}_{2} \mathrm{~S}^{(4,7)}$.

Our data supports that CSE expression increased during the gastric damage induced by ethanol and it suggests the involvement of $\mathrm{H}_{2} \mathrm{~S}$ during this event. Because the CSE/ $\mathrm{H}_{2} \mathrm{~S}$ pathway is also involved in regulating gastrophaty induced by ethanol these observations raise the possibility of $\mathrm{H}_{2} \mathrm{~S}$-modifying agents being used to improve resistance to gastric mucosa injury. Overall, our incomplete understanding of the role and mechanisms of action of $\mathrm{H}_{2} \mathrm{~S}$ in many aspects of physiology and pathophysiology of the gastrintestinal tract provides a field for extensive research in the future.

\section{CONCLUSIONS}

We conclude that the expression of CBS appears to be constitutive and diffuse across the gastric epithelium, while the expression of CSE appears to be induced in parietal cells by damage agents such as ethanol. Thus, future studies need to address the relevance of CBS and CSE produced $\mathrm{H}_{2} \mathrm{~S}$ for the signaling and gastroprotect effects.

\section{ACKNOWLEDGMENTS}

We appreciate the excellent technical support of Maria Silvandira. The authors gratefully acknowledge the financial support from Research Foundation for the State of Piaui (FAPEPI) and National Council of Technological and Scientific Development (CNPq) (Brazil). 
Medeiros JVR, Soares PMG, Brito GAC, Souza MHLP. Abordagem imunoistoquímica revela a localização de cistationina- $\gamma$-liase e cistationina- $\beta$-sintetase na lesão da mucosa gástrica induzida por etanol em camundongos. Arq Gastroenterol. 2013,50(2):157-60.

RESUMO - Contexto - O sulfeto de hidrogênio $\left(\mathrm{H}_{2} \mathrm{~S}\right)$ tem sido mostrado como um neuromodulador e contribuidor para a manutenção da integridade da mucosa gástrica na lesão causada por drogas antiinflamatórias não esteroidais. Previamente, demonstramos que a síntese de $\mathrm{H}_{2} \mathrm{~S}$ é essencial para a proteção da mucosa gástrica contra a administração de etanol. Objetivo - Para compreender o papel do $\mathrm{H}_{2} \mathrm{~S}$ e a localização detalhada de sua produção no estômago normal e após lesão induzida pela administração de etanol, estudou-se a expressão das isoformas cistationina- $\gamma$-liase (CSE) e cistationina- $\beta$-sintetase (CBS) na mucosa gástrica de camundongos tratados com salina ou etanol $50 \%$. Métodos - Os camundongos foram tratados por gavagem com salina ou etanol 50\% (0,5 mL/25 g). Após 1 hora, os camundongos foram sacrificados e os tecidos gástricos foram avaliados por análise histológica e imunoistoquímica específica para CBS e CSE. Resultados - Foi demonstrado expressão não específica de CBS na mucosa gástrica normal e expressão de CSE ocorrendo principalmente nas células parietais dos animais tratados com etanol. Conclusão - Assim, demonstramos que a expressão de CBS parece ser constitutiva e difusa através do epitélio gástrico, enquanto a expressão de CSE parece ser induzida nas células parietais por agentes lesivos como o etanol.

DESCRITORES - Mucosa gástrica. Cistationina- $\beta$-Sintase. Cistationina- $\gamma$-Liase. Etanol. Imunoistoquímica. Camundongos.

\section{REFERENCES}

1. Costa NR, Silva RO, Nicolau LA, Lucetti LT, Santana AP, Aragão KS, Soares PM, Ribeiro RA, Souza MH, Barbosa AL, Medeiros JV. Role of soluble guanylate cyclase activation in the gastroprotective effect of the HO-1/CO pathway against alendronate-induced gastric damage in rats. Eur J Pharmacol. 2013;700:51-9.

2. Dal-Secco D, Cunha TM, Freitas A, Alves-Filho JC, Souto FO, Fukada SY, Grespan R, Alencar NM, Neto AF, Rossi MA, Ferreira SH, Hothersall JS, Cunha FQ. Hydrogen sulfide augments neutrophil migration through enhancement of adhesion molecule expression and prevention of CXCR2 internalization: role of ATP-sensitive potassium channels. J Immunol. 2008;181:4287-98.

3. Fiorucci S, Antonelli E, Distrutti E, Rizzo G, Mencarelli A, Orlandi S, Zanardo R, Renga B, Di Sante M, Morelli A, Cirino G, Wallace JL. Inhibition of hydrogen sulfide generation contributes to gastric injury caused by anti-inflammatory nonsteroidal drugs. Gastroenterology. 2005;129:1210-24.

4. Fiorucci S, Distrutti E, Cirino G, Wallace JL. The emerging roles of hydrogen sulfide in the gastrointestinal tract and liver. Gastroenterology. 2006;131:259-71.

5. Gottfried EB, Korsten MA, Lieber CS. Alcohol-induced gastric and duodenal lesions in man. Am J Gastroenterol. 1978;70:587-92.

6. Guslandi M. Effect of ethanol on the gastric mucosa. Dig Dis. 1987;5:21-32.

7. Ishii I, Akahoshi N, Yu XN, Kobayashi Y, Namekata K, Komaki G, Kimura H. Murine cystathionine gamma-lyase: complete cDNA and genomic sequences, promoter activity, tissue distribution and developmental expression. Biochem J. 2004;381:113-23
8. Mariggiò MA, Minunno V, Riccardi S, Santacroce R, De Rinaldis P, Fumarulo R. Sulfide enhancement of PMN apoptosis. Immunopharmacol Immunotoxicol. 1998;20:399-408.

9. Medeiros JVR, Gadelha GG, Lima SJ, Garcia JA, Soares PMG, Santos AA, Brito GAC, Ribeiro RA, Souza MHLP. Role of the NO/cGMP/KATP pathway in the protective effects of sildenafil against ethanol-induced gastric damage in rats. $\mathrm{Br}$ J Pharmacol. 2008;153:721-7.

10. Medeiros JV, Bezerra VH, Gomes AS, Barbosa AL, Lima Jr. RC, Soares PM, Brito GA, Ribeiro RA, Cunha FQ, Souza MH. Hydrogen sulfide prevents ethanol-induced gastric damage in mice: role of ATP-sensitive potassium channels and capsaicin-sensitive primary afferent neurons. J Pharmacol Exp Ther 2009;330:764-70.

11. Valitutti S, Castellino F, Musiani P. Effect of sulfurous (thermal) water on T-lymphocyte proliferative response. Ann Allergy. 1990;65:463-8.

12. Vargas JE, Mudd SH, Waisbren SE, Levy HL. Maternal $\gamma$-cystathionase deficiency: absence of both teratogenic effects and pregnancy complications. Am J Obstet Gynecol. 1999;181:753-5.

13. Wang R. Two's company, three's a crowd: can H2S be the third endogenous gaseous transmitter? Faseb J. 2002;16:1792-8.

14. Yang G, Cao K, Wu L, Wang, R. Cystathionine gamma-lyase overexpression inhibits cell proliferation via a H2S-dependent modulation of ERK1/2 phosphorylation and p21Cip/WAK-1. J Biol Chem 2004;279:49199-205.

Received 15/2/2013. Accepted 12/3/2013. 